\section{INDIAN STAR TORTOISE (GEOCHELONE ELEGANS) FEEDING ON SLUG}

\author{
Indra R. Gadhvi \\ Lecturer, Zoology Department, Sir. P.P. Institute of Science, \\ Bhavnagar, Gujarat 364002, India
}

On August 5, 2000 at 0900hrs, 1 saw a tortoise outside the fencing wall of my garden. I caught the tortoise for identification and measurements. It was an adult male (it had concave plastron and longer tail) Indian Star Tortoise (Geochelone elegans). The body measurements were: straight carapace length $19.25 \mathrm{~cm}$, carapace height $10.20 \mathrm{~cm}$, and body weight $1118.00 \mathrm{~g}$. On the basis of its body markings and shell condition I assume that the tortoise might have escaped from a private collection. I kept the tortoise for a month in captivity. An enclosure measuring $2 \times 2 \mathrm{~m}$ with $30 \mathrm{~cm}$ high peripheral wall was built in one corner of my garden in such a way that the tortoise received sunlight regularly for at least for four to five hours a day. A shallow plate, filled with water was kept in a corner for drinking. I regularly offered vegetables as food, which included a few leaves of Euphorbia sp., different vegetables from kitchen waste and grasses (mostly
On the morning of August 27, 2000, at the time of feeding, I observed the tortoise feeding on a black coloured slug. It had already eaten the anterior portion of the slug. The slug was identified as a Vaginulus sp. with the help of a manual of practical zoology (Nair, 1994).

The species Geochelone elegans is known to be omnivorous and feeds on different types of vegetables and in captivity, it also feeds on snails and excreta of birds and animals (Daniel, 1983). Das (1995) mentioned that the species is largely herbivorous in nature but in captivity is known to eat animals, including West African Land Snail (Achatina fulica). The phenomenon of eating animals perhaps applies only to captive specimens deprived of a complete natural diet (Whitaker, 1974). Thus the present observation supports that, the species becomes carnivorous in captivity and the slug (Vaginulus sp.) is an addition to the list of dietary items of the species,

I am thankful to Dr. Raju Vyas for his useful suggestions, guidance and encouragement.

\section{References}

Daniel, J.C. (1983). The Book of Indian Reptiles. The Bombay Natural History Society, Bombay, $141 \mathrm{pp}$.

Das, I. (1995). Turtles and Tortoises of India. World Wide Fund For Nature - India/ Oxford University Press, Bombay, 176 pp.

Nair, P.K.G. (1994). A Manual of Practical Zoology Vol. I, Nonchordate. Himalaya Publishing House, Delhi, pp. 171-172.

Whitaker, R. (1974). Feeding habits of the star tortoise Geochelone elegans. Journal of the Bombay Natural History Society 71(1): 147-148. 